\title{
12
}

\section{THE INVOLUNTARY ETHNOGRAPHER AND AN EAGERNESS TO KNOW}

\author{
Sofie Strandén-Backa
}

One Saturday in September 2011, I was about to wash my carpets in the basement in the apartment building I used to live in. I put the carpets to soak in the morning. Later that day, my husband and I went down to the laundry room to deal with the carpets. The door was open. A young woman with long dark hair, dressed in silky black clothes, was also there, starting to wash her carpets. After some practical rearrangements, the three of us got started with our carpets - my husband and I with pine soap and a brush in the tubs, she on the floor with a brush on a stick. I admired her way of washing her carpets, and told her so, too. She, on the other hand, was wondering why I did not let the washing machine do the job. I pointed at a note on the wall and told her that it was not allowed to use the washing machine for this purpose. We talked a bit about this and that, as much as it was possible in the noise.

This practice of washing carpets is not something I do on a daily basis, but still, it is an everyday situation. Even though washing can be studied for its layers of meanings, so beautifully shown by Verdier (1981), Kaufmann (1998) and Klepp (2006), I had no intentions to continue this quest during this particular day. I never intended my carpet washing Saturday to be of any greater importance, and I certainly did not plan for it to be the starting point of a two-day long ethnographic event with several participants. Still, it became a "thick moment" - in analogy with Geertz's (1973) notion of thick description - that has returned to my mind many times, always with a puzzling feeling because of the absurd setting. What was it that really happened during these days? And, what did I miss?

Ethnographic fieldwork is ideally described as carefully planned and designed. The ethnographers have good pre-knowledge of what is going to take place and about the content of their study. The right persons have been contacted beforehand and given their informed consent of participation. The ethnographers enter the roles of the researchers as they get started, and take part in the events with a 
clear aim of research and a set of methodological and theoretical tools. This was, however, not the case in this study, which deals with my unexpected encounters with a Finnish Romany woman. Focusing on the non-linear in ethnography is a growing field of interest (see Smith and Delamont 2019). The overreaching aim of this chapter is to show the importance of an ethnographic process that is not linear and strict, nor foreseeable and controllable. That is precisely why a new understanding can be drawn from the surprises, ruptures and crises of it. As Halstead, I do not see a crisis as a problem, but as "a notion that facilitates the transformative spaces in which ethnographers do fieldwork and produce their ethnographies" (Halstead 2008, 2). A crisis is, at its best, something you learn from.

\section{The Finnish Romany}

Writing about the Romany is difficult for a number of reasons. Not only are they viewed as a relatively closed group and, having their reasons, not wanting to let other people know about their ways. For centuries, this ethnic group has been persecuted by authorities throughout Europe, its members have been accused of a vast number of crimes, and their children have even been taken away from them in the name of decency and civilisation (Rekola 2015; Tervonen 2015). The Romany group is hard to grasp and one troublesome feature comes up already when naming it (see Rekola 2015). The neutral term - today - is Romany. Not long ago it was gypsy (Swedish: zigenare, Finnish: mustalainen). The group has also been called "tattare" in both Swedish and Finnish languages, a misleading term, and not well seen today. The term Romany is also problematic in many ways, since it covers a wide range of ethnic groups in Europe with perhaps more differences than similarities (see Tervonen and Enache 2015). The Finnish Romany people call themselves "kaale" in Finnish or "kàlo" in Romany, a term that is relatively unknown outside the community, and therefore I have chosen not to use it in this text. I use the term "Romany". I also use the term "gypsy" when I wish to show stereotypes and prejudices. As I see it, the stereotypes have been sticking to the word gypsy (see Ahmed 2004, 11, 63-64).

In Finland, the Romany have been categorized as a so called "old-minority" together with the Saami, the Tatars, the Jews, the Russians that moved to Finland prior to 1917, and the Finland-Swedes. All of these have their own respective and specific history and position, which differ greatly from one another (Tuori 2009, 29, 69). The Romany people has been discriminated and subjected to violence based on ideas of race (Tuori 2009, 72), while the Finland-Swedish people is differentiated due to language, and stereotypically viewed as "the Swedish-speaking better people" (Klinkmann 2017). I am Finland-Swedish, from the rural region of Ostrobothnia, a geo-linguistic position that is viewed as quite the opposite to the capital city of Helsinki (Strandén-Backa and Backa 2017). While the FinlandSwedes as a group are well-educated with their own Swedish-speaking university Åbo Akademi, the Romany got their first Romany language teachers in the 1980s (Friman-Korpela 2015, 237). The Finland-Swedes have been called the most 
studied group in Finland, but when it comes to the Romany, much remains to be done, particularly from an emic perspective.

Bearing in mind the pain that, according to feminist philosopher Adriana Cavarero (2000), occurs when other people do not see who you are, just what you are - in this case a Romany woman and a non-Romany woman (valkolainen/ kaaje) - I would like to unfold my own taken for granted ideas of an imagined ethnographic script and my feelings of hurt and frustration when I could not act according to it because the script was not accepted by the rest of the participants. It felt as if the rest were acting according to another script, one that I was not introduced to. As an analytical tool for this chapter, I will therefore use concepts that originate from Erving Goffman's famous The Presentation of Self in Everyday life (1959). The perspectives that he introduces are those from a theatrical performance in order to study how individuals present themselves and their activities to others, how individuals guide and control the impression that others form of them. It is important to keep in mind that an everyday event studied in this manner is reciprocal, in the sense that there are at least as many plays as there are participants. There are no stars or leading roles. This is certainly true when it comes to my own experiences of washing carpets.

\section{Washing carpets}

I liked talking to this woman - let us call her Rosita - but, at the same time, I felt a bit uncomfortable, partly because of the language. I am not as fluent in Finnish as I would like to be despite my ten years of Finnish classes at school, and it is difficult to hear in a noisy place such as the laundry room. But there were other things, too, things I did not understand from Rosita's behaviour. My washing project kept me in the basement until I was done with the carpets, but Rosita had a constant connection to the world outside. In my view, she ran around most of the time - in and out of the basement, making several short phone calls, instead of focusing on the job at hand. Once a woman in big skirts knocked on the basement window, and Rosita immediately went out to her. Then I started to think that Rosita was Romany, and when she once returned from her visit to the outer world wearing her beautiful black velvet skirt, white blouse and ornament jacket, I finally became sure of her ethnic background. Some of the Finnish Romany women choose to wear their traditional dress, which distinguishes them visually from the majority of the population. It is not just any dress, but carefully sewn to fit. It is an expensive dress, as it is custom made with many parts sewn by hand, and also because of the amount of fabric. Approximately ten meters of velvet is needed for the skirt.

When Rosita entered the laundry room, she took her traditional clothes off before starting to work with her black and silky clothes on, and it was not until then I realised that her black clothes actually were her undergarments. To my surprise she was working only partially dressed, despite the fact that my husband was present, and his presence did not seem to bother her. When she was about to set off again, she said: "On with the skirts again." I looked up and asked her how 
much they weigh, and she told me that the dress weighs about ten kilogrammes. She told me that she had a chronic back pain because of her heavy dress, and continued to say that she did not want to use it if it were not for the fact that she was obliged to wear it. I asked her why she felt she had to wear it, and she told me that the dress is a mark for her being a grown-up woman.

\section{A job offer}

Finally, my husband had to leave, and I stayed in the laundry room to finish up. All of a sudden something happened that took me by surprise. Rosita asked me if I was busy and had a lot of work to do, and since I did not give her an answer right away, she asked me if I had a job. Back then, I was in the middle of a research project, I taught at the university, and beside this I had some extra studies at the business school. She explained why she had asked me, and the reason was that she wanted me to help her to clean every now and then. I was stunned, and I did not know what to say. She told me that she would take part in the cleaning, and that she would pay me, but that the payment would not necessary need to go by the book. So there I was with my shining new $\mathrm{PhD}$ and was offered an under the table job by a gypsy woman. Everything felt upside down.

I was saved by another of Rosita's telephone calls, and got a couple of minutes' time to collect my thoughts. When she asked me again, I told her that I both worked and studied, but that I could ask my students. This was an excellent idea, according to her, and she encouraged me to keep in touch. She said that she wanted help with cleaning the windows and dusting on top of cupboards - her culture did not allow her to do this herself. And I got curious, of course, and wanted to know more. I thought that now I had an opportunity to learn more about Romany culture and traditions. Rosita seemed to be open and talkative. When she learnt that I was studying, she lit up, and told me that she was going to start studying. She wanted to become a social worker, but lacked the school grades. She pointed out that Romany people nowadays want to study and work. Rosita was very proud of her brother who just had been appointed leading welfare worker in a congregation. She told me he was helping poor people with food and clothes. She told me her Swedish-sounding surname, and asked if I knew what it meant. When I said that I did not know, she asked if it does not mean "honest". I explained that there was one letter too much.

I thanked her for asking me about the job and for the language immersion in the laundry room. I told her that if she wanted to practise Swedish with someone, now that she was going to study, she could practise with me. She looked happy, and seemed to realise that this was an opportunity for her. She asked me if I could teach her Swedish and write her a certificate. I promised her to try, but I explained that I, in exchange, wanted her to teach me about her culture. She asked me when I could come over to her apartment, and we scheduled our first lesson for the following day, which was Sunday. This suited her well, and she suggested that I would come for a visit at $4 \mathrm{pm}$. I explained to her that I have a 
food intolerance that requires a special diet, and that I say to people that I visit them for their company, not for the food. But she answered that it is different in her culture - all guests have to be treated with something to drink, and preferably, also something to eat. She asked me if I drink juice, and I said yes, and she made sure that I would come the following day.

\section{A Swedish teacher popping in}

On Sunday afternoon, I felt both excited and nervous. I thought about what I would learn and whether or not I would get access to unknown territories. I wondered what I had put myself up to, what I would do and how I would be able to teach Rosita Swedish. I was a bit worried about breaking some sort of taboo and messing things up. According to Viljanen, the grounding pillars of Romany culture are honour, decency, and a literal and symbolic purity (Viljanen 2015, 395). I also thought about possible physical dangers. As a teenager, I was taught to watch out especially for Romany women, since they were said to be prone to violence, while male gypsies were not considered a threat. When I rang the doorbell of her apartment just before $4 \mathrm{pm}$, I felt pretty stupid, but the door was answered by a bright-eyed girl of school age and I asked for Rosita. She showed me to the sofa where Rosita was sitting next to the woman who had peeped in through the basement window the day before. I got a bit surprised when I entered. There were three grown up women and two girls and it did not seem as if it were going to be any Swedish lesson. I was invited to enter. In the kitchen, there was a slightly older woman and she held out her hand. I took it and told her my name. She introduced herself as Rosita's cousin. She asked if I was "that cleaning lady", but I told her that I was not. Rosita told the other women to make room for me between them in the sofa.

Earlier that day I had been picking apples at a friend's house, and with a vague notion about Romany rules of purity, I made sure to pick the apples directly from the tree and not putting the plastic bag on the floor. I had in mind that things that had been on the floor or on the ground were considered unclean. I held out my plastic bag with apples. I explained that I had picked them the same day, and I put them down on a table. Then I sat down on the sofa. It was cramped for room and I felt small between the big skirts. The two girls wanted to try the apples right away and Rosita also asked for one. I said that they might be a bit sour, but she told me that she liked them. She asked if I had brought any books, but I explained that I wanted to talk to her about her studies before we got started.

The other two women in the apartment wanted me to be the cleaning lady, and they complained that their legs hurt and that they needed help with the cleaning. The older woman encouraged the other one to show me her legs. She stood in front of me as I was sitting on the sofa, pulled up her skirts right in front of my nose, showed me her legs, lamented and tried to convince me that I really had to help them with their cleaning. Rosita explained to them that she had asked me already, and she told them that I had promised to ask my students. The two 
women went out on the balcony to have a cigarette - a tobacco treat was obviously expected of Rosita. Rosita thought that it probably would be better if we had our lesson some other time when she was alone, and I agreed. It seemed to me that she could not ask the older women to leave her apartment. And personally, I just wanted to get out of there. We decided to meet the next evening instead. I said goodbye and went home.

\section{The dress that made me think}

There was nothing extraordinary with Rosita's and my first acquaintance. I was experiencing my ordinary feeling of anxiety when having to cope in the Finnish language, and my need to position myself against the stereotype of snobbish Swedish-speakers who just do not want to speak Finnish. I thought it was strange to wear black silky clothes while washing carpets. But when I saw Rosita entering the laundry room in her traditional dress, everything changed in a second. I understood that she was something very specific that I was not. The female Finnish Romany dress is a key symbol in many ways. The dress is part of the identity of Romany women in Finland. For them it is a symbol of pride and distinction of Romany culture and belonging, while for the non-Romany majority it is a factor of segregation, of otherness. To the majority of the population it is a strong marker, combined with stereotypes and behaviour that are not seen as valuable. Romany people are stereotypically not viewed as honest and trustworthy Finnish citizens. They are said to con, lie and steal, and to be unwilling to have a decent job and to rely on the Finnish welfare system. They are still viewed as criminally burdened, with a lot of alcohol, drugs, thefts, fights and even killing. Seeing this dress, all the culturally transmitted non-Romany knowledge about the group categorized as Romany overwhelmed me. Prejudice of various kinds is deeply rooted in common knowledge and popular imagination.

As I noticed the difference between Rosita and myself, I immediately categorised her as "the Other", and got more cautious. This piece of culturally transmitted knowledge is like a filter I had to deal with, something risking to distort my perception. In this particular case, I wanted to appear as extra nice, since I did not want Rosita to believe that I was one of "those people" with stereotypical opinions of her ethnic group. But, of course, I am affected by the cultural values circulating in the community where I have spent my whole life. At the same time, I also got less nervous about my non-fluent Finnish. It was as if we had something in common as none of us were part of the Finnish majority population, even though Rosita's mother tongue is Finnish, and I, based on my looks, quite likely, would pass as Finnish. To Rosita I was nevertheless a member of the majority population.

If we borrow the usage of back stage and front stage from Goffman (1959, 9799), we can see that Rosita definitely considered the laundry room as back stage. She took her traditional skirt off there - most likely because she did not want it to get wet - and changed back into her dress when leaving the basement. I suppose that she must have felt at ease. Otherwise she would not have worked in clothes 
that she considered as underwear in public. She commented her own changing of clothes with "On with the skirts again" as she was entering the role of an adult Romany woman (Viljanen 2015, 398). Certain clothes, for example, can, according to Goffman, become institutionalized social facades in the sense that they give rise to abstract, stereotypical expectations. Goffman states: "The facade becomes a collective representation and a reality by its own force" (Goffman 1959, 33). Rosita's reflective comment made me pause in what I was doing, as I realized that it was not just any dress she put on. I did not know what to say, so I asked about the weight and was amazed by it. Physically the dress is a heavy burden, and Rosita also complained about chronic pain since starting using it. To me it seems that the dress also metaphorically can be seen as a burden since it is a marker that produces a stigma in the view of the non-Romany population (see Viljanen 2015, 390-392). And the sticky (see Ahmed 2004) stigma of "gypsyhood" is hard to bear: stealing, lying, cheating, and fighting. Rosita commented directly on some of these stereotypes and thus positioning herself and her peers against the flourishing stereotypes.

The laundry room was the only place I saw her without her dress. In her apartment she appeared fully dressed, even though a person's home usually is viewed as typically back stage in comparison to public domains (Goffman 1959, 106-108). Anything else would not have been possible, since she was in the company of elder Romany women. I have learnt later, that since the kitchen is considered pure, the traditional dress is required there (Viljanen 2015, 398). Rosita treated me like any other person, and, in some way, I believe she liked me, too. At least she felt safe to ask me whether I could be her cleaning company. During our talk in the laundry room, I made sure that I did not have the time for that, and I thought the whole thing was over with. But later, in her apartment, the two older women took me for the cleaning lady that they all so desperately seemed to be in need of. I was thrown into a play I did not want to take part in, when one of them enacted what Goffman calls an "idealisation" (1959, 39), that of the poor gypsy woman suffering from her aching legs due to her heavy dress. By doing this, she wanted to convince me that I really needed to help them with their cleaning. But, at the same time, it felt threatening and provocative. To be honest, I was afraid in Rosita's apartment, and I did not want to be there any longer than necessary in order not to be impolite to her. Many years later, I have been told by a woman, who is a layman expert on Romany culture after working for many years at a public sauna, that this kind of behaviour is a common test of whether it can make the valkolainen, the white person, afraid. It did, but I managed to keep cool, and did not reveal my real feelings, but continued to show my sympathies for their aching legs. At the same time this event is full of culturally interesting meanings, meanings that $\mathrm{I}$, at the moment, did not manage to decode.

In Rosita's apartment I was directly interacting with three adult Romany women. And I was an intruder, even though I had an invitation. Obviously, Rosita had visitors that she did not expect, and she was forced into a situation that was impossible to handle since she was acting in two different plays simultaneously. Goffman $(1959,123)$ talks about the problems that appear when the participants 
fail in keeping two audiences apart, when an outsider happens to take part in a play that was not meant for him or her. The two other Romany women were intruders in the play that I and Rosita were involved in, that is teaching Swedish and learning more about Finnish Romany culture. And I was an intruder in another play, just because I was a white person who refused to be their cleaning lady. It is natural that a certain amount of confusion appeared, and I just felt that I was the wrong person, at the wrong place and at the wrong time. I was looking for a back stage pass into the fascinating world of the Finnish Romany population, but there seemed to be plenty of pitfalls and obstacles that I was not aware of.

\section{"The gypsy fight" in the parking lot}

Back in my apartment, I heard loud and high-pitched screams as if several people were in life-threatening danger. The screams did not stop, so I went to the window and looked out. In the parking lot behind a couple of trees, I saw the legs of a woman kicking fiercely. I also saw a whole bunch of women in traditional skirts. I could see that other people from the block of flats were outside watching. The yelling continued, and I thought it best to go out and take a look. I even thought that someone could be harassing Rosita because of me.

The other residents were gathered at a safe distance. I wanted to go nearer and see what was going on, but I did not get any closer than a couple of cars away from the main stage. The two little girls from Rosita's apartment were hiding behind one of the cars, and they were crying with tears running down their cheeks. I asked them what was going on, and they told me that their mother and aunt were fighting. I saw an upset unknown woman with blood smeared all over her mouth and to me it was a truly scary sight. I turned to the girls and asked them if anyone had hurt them, but they shook their heads. A man approached the girls and told them to go inside, but they did not want to. I told them to come and sit with me in the swing, and so they did. They sat there for just a little while, and then ran back to their relatives when the situation had calmed down a bit. I could still hear the angry sisters screaming, but I could not catch the words. The only thing I could hear was the older woman from Rosita's apartment encouraging the two women to fight each other.

It felt like I had a ringside seat in a theatre during a very realistic and scary play. The stage was the parking lot between the garage and the dust bins, and the actors were convincing in their roles. It felt as if the participants in the fight were conscious of acting in front of an audience, like they were staging their "gypsyhood" in a strange strategic essentialist manner (Spivac 1993) in front of a grateful audience who, once again, got their prejudice manifested. The non-Romany audience, once again, got confirmed how "those gypsy people" behave. My eyes met the eyes of the younger woman from the apartment, and what I saw was something that I interpreted as a combination of pride and challenge - this is how we, the "gypsies", are. This woman chose another way than Rosita did when coping with stereotypes about the "gypsies"; it was like she acted them out through her 
challenging gaze. Earlier that day I had asked to know more about Romany culture, and now I got it shoved into my face. It felt like Rosita and the rest of the persons in the parking lot were enacting the type figures of "The Romany" and "The Gypsy" (see Strandén 2010).

Rosita was, of course, outside as well, trying to put an end to the fight. I approached her to ask what the whole thing was about, and she said that it had been just a little fight between sisters, and that everything was all right by now. I felt strange. I had just been given the role as a border-being, someone with passage to two different spheres, although a limited passage to one of them. An hour earlier, I had met three of the women and the two girls back stage on their home ground. I had been friendly and shown my interest towards them, despite my feelings of uneasiness. During this short period of time, I felt that I had won some kind of confidence - I thought I was given a back stage pass. I did not behave like the rest of the non-Romany audience. I reached the edge of the stage which changed my role into a walker-on, someone without a part of her own. But I was an actress without any screenplay. When I approached the stage, I felt unsure whether or not I would become physically or verbally assaulted as I was stumbling around in the play "The Gypsy Fight". I was really surprised when the two girls let me lead them away from the stage into the side stage when their male relative did not succeed. At the same time, I felt that I had gained some kind of respect due to my acting. I did not put my nose in, I did not try to break the fight off, but neither did I stand far away and watch the spectacle from a safe distance. I felt alarmed, but I wanted to act like a "good citizen", and I was happy with my role, which I felt was a success.

\section{An annoying eagerness to know}

This could be the story about how I met my Romany friend Rosita, how I had many discussions with her over the years while teaching her Swedish and how I was invited to learn about her life and the ways of the Finnish Romany people. But this is not the story.

On Monday evening I rang the doorbell, as agreed, but despite me hearing someone being at home, the door remained locked. I never saw Rosita again, and the next day I saw the apples that I had given her scattered on the ground. At the time, I did not know what had happened. One thing I knew for sure was that I felt hurt, both by the clear rejection of my well-meaning gift and by the door that was shut despite her invitation.

Regarding the events accounted for above, one can dwell upon aspects of power, as both I and the Romany women had hierarchical and cultural ideas about each other. While the non-Romany community harbour deep prejudice against Romany people, the same is also true vice versa (see Okely 2008). According to Viljanen, the Romany struggle for purity and against impurity is not only about the literal and symbolic meaning, but also about a multidimensional cultural structure building on knowledge of the Romany identity. The Romany 
continually identify and measure each other based upon criteria of purity and honourability, and these criteria are also used to draw lines of their ethnicity within the group and, in particular, against non-Romany people. Persons belonging to other Romany groups and non-Romany usually neither notice nor understand these messages (Viljanen 2015, 399). During one instance, I clearly felt I was put to test and that was the uncomfortable situation when having someone's bare leg right in front of my face. What I did not know then, is that feet and legs are considered impure by the Romany (Viljanen 2015, 401). This act can be seen as a combination of a test and an insult. Since the feet and the lower part of the body are impure, everything that gets in contact with it becomes impure - hence carpets are impure textiles (Viljanen, 2015, 398). Since I was someone dealing with washing carpets, I was the right kind of person to ask to do cleaning chores for them, things they could not do themselves. In order to solve this part of my mystery case, the only thing that will help, is to learn more about the Finnish Romany culture.

When it comes to the part where Rosita did not open her door despite her invitation, I can only speculate. One reason could be that she was feeling threatened by her peers because of her socialising with me. I can be seen as a representative of the research community, one, that prior to the 1960 s, showed an interest in the Romany in order to change them, to assimilate them more effectively. There has been widespread suspicion towards the majority population (Viljanen 2015, 385). This suspicion might also have been awakened by me handling the two crying girls during the fight in the parking lot. As a part of the assimilation plan, many of the Romany children were taken away from their families, and I suspect that there are all too many wounds to heal. Not knowingly, on a symbolic level, I did the same as the authorities and the Romany mission did for decades, that is putting the children in a safe place away from their family.

"Involuntary" is perhaps a word that is too much of a twist, but, in many senses, this is how I feel about the whole thing. This chapter is based on my experiences from an unplanned ethnographic event - I just wanted to wash my carpet. Then I realised that Rosita could offer a gateway into a community that has fascinated me ever since I, as a child, was watching the Romany women in their beautiful clothes and golden jewellery, the overwhelming flower decorations on the graves in the churchyard and the big Mercedes cars - their exotic Otherness. Yet, my brief knowledge of the complicated taboo system, their presumed negative attitudes towards white people, and the violent and criminal reputation made me feel cautious. But my curiosity was awakened and started an analytical process. The feeling of being involuntary is, thus, partly due to my training as a cultural analytical folklorist. I have been trained to stop and think in situations where my emotions start signalling, because there might be a situation at hand where the normative and what is taken for granted is contested (see Strandén-Backa 2013; Nilsson and Marander-Eklund 2018). However, I am not used to meeting neither silent nor open hostility towards myself. I am used to noticing details and carefully scrutinizing them in order to find out deeper levels of meaning, but in this case nothing made any sense to me because I lacked the necessary knowledge. The ethnographic 
moment that I have unfolded here has a somewhat dreamlike quality. As in a dream, I was thrown into situations I could not control, that seemed "queer", upside-down and even bizarre. The feeling that "anything can happen" never left me, and the logic was out of my reach. And indeed, it is a thick moment filled with symbols: a black silky dress, in the basement, a woman's leg in my face, a bloody fight in the parking lot, and apples on asphalt.

Writing this text, I have been struggling with questions concerning research ethics. I would like to appear as a neutral and objective researcher before my audience, but since I have chosen to reveal my prejudice and stereotypical beliefs, I let everyone know my low standards as a person. I definitely had my doubts about writing this text, and I still do. I have even been advised not to publish it because of the many problems arising when dealing with people that meet cultural negative expectations. In an interview with female Romany painter/writer Kiba Lumberg, she talks about problems arising when trying to have an open dialogue about the culture specific violence and subordination of women that, according to her, is frequent within the Romany community: "If a Romany deals with these issues, he or she receives threats of violence from the Romany population, and if someone from the majority population touches these matters, he or she is called a racist" (Bruun 2013). In many ways, it feels as if this is a case of ethnography seeking its ethnographer. Now it has found me, the involuntary ethnographer with all her doubts, giving me this problem: I cannot let go of this case - it haunts me like an unsolved criminal case haunts a retired detective. I do not want to get my hands dirty, but I need to close this case.

\section{References}

Ahmed, S. 2004. The Cultural Politics of Emotion. New York: Routledge.

Bruun, J. 2013. Tystnaden är den största skymfen, 34-39. Astra 3. www.astra.fi/wp-content/ uploads/2013/10/astra_03_nät_kibaintervju.pdf

Cavarero, A. 2000. Relating Narratives: Storytelling and Selfhood. London and New York: Routledge.

Friman-Korpela, S. 2015. Den finskromanska politikens internationella förbindelser. In De finska romernas historia från svenska tiden till 2000-talet, edited by P. Pulma, 226-251. Helsingfors: Svenska litteratursällskapet.

Geertz, C. 1973. Thick description: Toward an interpretive theory of culture. In C. Geertz, The Interpretation of Cultures: Selected Essays. New York: Basic Books.

Goffman, E. 1959. The Presentation of Self in Everyday Life. New York: Anchor Books.

Halstead, N. 2008. The ethnographic present: Knowing through crisis. In Knowing How to Know: Fieldwork and the Ethnographic Present, edited by N. Halstead, E. Hirsh, and J. Okely, 1-20. New York: Berghahn Books.

Kaufmann, J-C. 1998. Dirty Linen: Couples Seen Through their Laundry. London: Middlesex University Press.

Klepp, I. G. 2006. Skittentøyets kulturhistorie: Hvorfor kvinner vasker klar. Oslo: Novus.

Klinkmann, S-E. 2017. "Svenska talande bättre folket": Mellan ironi, stereotyp och humor. In Föreställda finlandssvenskheter: Intersektionella perspektiv på det svenska i Finland, edited by S-E. Klinkmann, B. Henriksson, and A. Häger, 301-328. Helsingfors: Svenska litteratursällskapet. 
Nilsson, F., and L. Marander-Eklund, eds. 2018. Under ytan: Kulturanalyser av det bortglömda, dolda och triviala. Åbo: Åbo Akademi.

Okely, J. 2008. Knowing how to know. In Knowing How to Know: Fieldwork and the Ethnographic Present, edited by N. Halstead, E. Hirsh, and J. Okely, 55-74. New York: Berghahn Books.

Rekola, T. 2015. Romernas tidiga skeden i Finland. Från 1500-talet till mitten av 1800talet. In De finska romernas historia frän svenska tiden till 2000-talet, edited by P. Pulma, 2082. Helsingfors and Stockholm: Svenska litteratursällskapet and Atlantis.

Smith, R. J., and S. Delamont, eds. 2019. The Lost Ethnographies: Methodological Insights from Projects That Never Were. Bingley: Emerald Publishing.

Spivak, G. C. 1993. Can the subaltern speak? In Colonial Discourse and Post-Colonial Theory: A Reader, edited by L. Chrisman and P. Williams, 66-111. New York: Harvester Wheatsheaf.

Strandén, S. 2010. "I eld, i blod, i frost, i svält": Möten med veteraners, lottors och sjuksköterskors berättande om krig. PhD diss, Åbo Akademi.

Strandén-Backa, S. 2013. Dealing with emotions. In Therapeutic Uses of Storytelling, edited by C. Asplund Ingemark, 85-100. Lund: Nordic Academic Press.

Strandén-Backa, S., and A. Backa. 2017. Den kategoriserade forskaren: Om självreflexiv intersektionalitetsanalys och normativ finlandssvenskhet. In Föreställda finlandssvenskheter: Intersektionella perspektiv på det svenska $i$ Finland, edited by S-E. Klinkmann, B. Henriksson, and A. Häger, 84-105. Helsingfors: Svenska litteratursällskapet.

Tervonen, M. 2015. Vagabonder och gränsöverskridare: Romer i den framväxande nationalstaten. In De finska romernas historia frän svenska tiden till 2000-talet, edited by P. Pulma, 83-139. Helsingfors: Svenska litteratursällskapet.

Tervonen, M., and A. Enache. 2015. De nyanlända. In De finska romernas historia från svenska tiden till 2000-talet, edited by P. Pulma, 282-285. Helsingfors: Svenska litteratursällskapet.

Tuori, S. 2009. The politics of multicultural encounters: Feminist postcolonial perspectives. $\mathrm{PhD}$ diss, Åbo Akademi.

Verdier, Y. 1981. Tvätterskan, sömmerskan, kokerskan: Livet $i$ en fransk by genom tre kvinnoyrken. Stockholm: Atlantis.

Viljanen, A. M. 2015. Den romska kulturens föränderliga former och permanenta strukturer. In De finska romernas historia frän svenska tiden till 2000-talet, edited by P. Pulma, 380-427. Helsingfors: Svenska litteratursällskapet. 